Wayside Shrines: Everyday Religion in Urban India

\title{
Shrines of Goa: Iconographic Formation and Popular Appeal
}

\section{Alexander Henn}

\section{CpenEdition}

\section{Journals}

\section{Electronic version}

URL: http://journals.openedition.org/samaj/4533

DOI: $10.4000 /$ samaj.4533

ISSN: 1960-6060

\section{Publisher}

Association pour la recherche sur l'Asie du Sud (ARAS)

\section{Electronic reference}

Alexander Henn, «Shrines of Goa: Iconographic Formation and Popular Appeal », South Asia

Multidisciplinary Academic Journal [Online], 18 | 2018, Online since 14 May 2018, connection on 20 April 2019. URL : http://journals.openedition.org/samaj/4533 ; DOI : 10.4000/samaj.4533

This text was automatically generated on 20 April 2019.

\section{(c) () $\ominus$}

This work is licensed under a Creative Commons Attribution-NonCommercial-NoDerivatives 4.0 International License. 


\title{
Shrines of Goa: Iconographic Formation and Popular Appeal
}

\author{
Alexander Henn
}

\section{Introduction}

1 Goa, like most regions of India, is scattered with religious structures and buildings. ${ }^{1}$ After almost half a millennium (1510-1961) of Portuguese colonialism and Catholic hegemony, Hindu temples and Catholic churches are most prevalent today in this small Indian state on South Asia's western coast, along with a large number of religious structures, both Hindu and Catholic, that fall into the vast category of "shrines."

The local language, Konkani, uses various terms to refer to these religious structures and buildings. Devalaia, the Konkani term for temple (Portuguese: templo, Old Portuguese: pagoda), and igroz, the term for church (Portuguese: igreja), designate and distinguish the major religious buildings associated with the Hindu and Christian traditions, respectively. For the many structures that, apart from some notable exceptions that I will elaborate on below, are smaller than temples and churches and whose qualification as "shrines" or "wayside shrines" I will analyze in this paper, there is no generic Konkani term in use in Goa. Some Konkani terms specify these structures by their different shapes and also indirectly identify their religious associations. Devuli, small temple, or gumptī, grottoshaped abode of gods or tutelary beings, are common terms for Hindu structures; kopel, chapel (Portuguese: capela), or khuris, cross (Portuguese: cruz), are designations for Catholic structures. Other Konkani terms specify religious structures by reference to their localities or sacred agents. They are, for instance, called śimeveilo, "the one on the border," or jāgeaco, "the one on the spot," or Pattoco, "the one on [the bridge called] Patto, " referring to tutelary beings that are taken to guard, inhabit, and mark critical boundaries and locations. In some villages, one can find Hindu gumptī, as well as Catholic khuris said to be the abode of rakhne or rakhandār, which is a common designation among Hindus and Catholics for "guardian" or tutelary being. It is also not rare for grotto-shaped structures, very similar to the ones that Hindus call gumpti, to contain icons and images of 
Catholic saints. ${ }^{3}$ Notably, these generally smaller religious structures constitute by far the majority of all religious structures to be seen in Goa today and are scattered in their hundreds, if not thousands, over the entire region. They mark the public spaces of villages, towns, and cities, including plazas, markets, and public buildings, and are also found at bridges and crossroads, on the sea shore, at the boundaries of fields and forests, and at many other locations.

When asking what distinguishes temples and churches, on the one hand, and shrines, on the other, it becomes clear that this is a complex issue. The most common, although mostly unspecified, use of the terms seems to suggest that shrines are smaller, more informal structures compared to the bigger, formalized structures of the temples and churches. Intriguingly, older literature, represented by Carl Gustav Diehl's description of the interrelation between "Church and Shrine" (1965) in the Lutheran Mission in Tamil Nadu, seems to imply that the former term refers exclusively to Christian structures and the latter to Hindu ones. ${ }^{4} \mathrm{~A}$ closer look reveals that things are indeed more complex. There is not one characteristic or criterion that can be said to mark a general or absolute difference or consistent distinction between the two types of religious structures. Instead, all differences turn out to mark gradual transitions, or reveal inconsistent differentiations that hold true in some cases, but are not valid or existent in others. Structures often described as wayside shrines, for instance, sometimes grow dramatically in size and popularity, especially in modern times and in urban environments, until they reach a point where it is difficult to say whether they still are shrines or rather deserve to be called temples or churches.

Moreover, the concept of the shrine in English and other European languages does not only designate structures that are distinguished from temples and churches. It is also used to refer to special sites within churches and temples, such as sanctuaries or altars, at which icons, images or other tokens of God or gods or saints are displayed or kept. In the Catholic tradition, it is this solemn function that explains why one of the meanings of the Old English term scrin is "chest." (The Oxford English Dictionary 1989 XV:376). Similarly, an old meaning of the German term Schrein is "Kästlein" (Zedler). Both terms stand today for the modern English term "shrine" and are used to mark reliquaries or containers of relics. In Portuguese, the term "shrine" translates simply as relicário. In fact, the Catholic canonical rule prescribing that for the consecration of a church a small chest containing a bodily relic from a saint or from Christ has to be embedded in the altar reveals that an essential structural part of every Catholic church is actually a shrine (Catholic Encyclopedia: consecration). ${ }^{5}$ Things become even more complex if one also considers the Catholic notion of "chapel," which in many ways also stands for "shrine." As Catholic ecclesiastical laws make clear, chapels may well be part of a church, with the main sanctuary often marked, for example, as capella major, but they also exist as independent wayside structures, especially alongside pilgrim routes (Catholic Encyclopedia: chapel). In the Hindu tradition, the equivalent of the Catholic inside shrine or capella major is the garbha grha, literally the "womb chamber" or inner sanctum of the temple, where the mürti or idol of the deity is placed (Mitterwallner 1981, 1983a, 1983b; Kowal 2001). This special place is also sanctified by solemn ceremonies, in particular the ritual installation of the mürti that marks the formal consecration of a temple. The conceptual and spatial proximity of shrine and icon is also highlighted by the fact that, until the onset of the twentieth century, the Portuguese term pagoda simply conflated the designations of " 
templo hindu" and "idolo indiano, imagem de deuses ou santos asiaticos" (Dalgado 1988 II:131,130).

5 By way of an initial, preliminary summary, it can be said, therefore, that the English term "shrine" is rather imprecise when confronted with the multiple structures, objects, and meanings that it is taken to represent in general and in Goa in particular. While the term is used to refer to structures that are distinctly different from churches and temples, it is also used for structural details that are essential to churches and temples. It is also not at all clear how the English term "shrine" relates to the terms that are taken to mark its equivalents in the local language Konkani.

6 These ambiguities notwithstanding, it is from a practical perspective clear that shrines are structures or containers or locations in which or at which, in diverse ways, the divine or holy is represented or embodied or present. Building on this assurance, I will focus in the following primarily on iconography as I attempt to elaborate a typology of processes and characteristics that go into the formation of shrines in Goa and that are essential to their formal status and popular appeal. Unlike classical iconographic studies, I will, however, put aside issues of art or art history and pursue instead an anthropological and, by implication, ethnographic perspective that scrutinizes above all practical and semiotic aspects. That means, I will look closely into the social practices of the patronizing and handling of the shrines and icons and will try to understand how details of their attributed emergence, agency, and effects influence the distinctions among them. My study is based on ethnographic research undertaken between 1990 and 2010, including long-term observation, formal and informal interviews, and the study of published and unpublished texts, images, photographs, and archival resources. I will examine both historical regions of Goa, the Old Conquests and the New Conquests, ${ }^{6}$ albeit selectively and without a claim to being comprehensive. The study is guided by the attempt to elucidate how the historical circumstances of Portuguese domination, Catholic hegemony, and local resilience have impacted the nature and history of the shrines. For comparative reasons, I also rely on research and material from Sawantwadi, the Konkanispeaking southernmost region of Maharashtra. My paper will be structured by elaborating on, for each of the two religious traditions, the characteristics, processes, and practices that go into and sustain the formalization of shrines Thereafter I will discuss characteristics of the popular appeal of some of the shrines, which, for Hindu shrines have to do with ways of their origination or emergence, for Catholic shrines with the ascribed miraculous nature of their icons. In general, I will attempt to advance the argument that the parameters and details that buttress or contest the validity of the concept of the shrine depend above all on the social practices that constitute shrines and the nature of the signs that they are said to hold or to represent.

\section{Hindu Shrines}

\section{Formalizations}

7 To argue that Hindu temples are formalized shrines highlights first of all their embeddedness in the hierarchies that structure the local Goan society. There are at least four interrelated sets of social hierarchy effective in Goan villages and towns. The first is the stratification of the four Hindu castes Brahman, Kshatriya, Vaishya and Sudra dominating the marginalized Dalit and tribal population. A second classification 
distinguishes the clans of ganvkar or elite villagers from common villagers by claiming the ganvkars' descent from the first settlers of the village and by granting them two eminent privileges. Ranked among themselves by principles of seniority in a hierarchy of vangods or clans, ganvkar clans had-and, to some extent, still have-a guaranteed permanent zon or share in the communal village land. The second privilege is that $\mathrm{g}$ anvkars, again stratified into first, second, third, etc. vangods, are distinguished as mahäjan , literally "great persons," and constitute the board of trustees, administrators, and ritual celebrants of the local temples. Finally, the ranking of castes, the distinction between $g$ anvkars and common villagers, and the stratification of the vangods, coincided with a fourth system of classification: the hierarchy of ritual honors, known as mān, that stratified the privileges and functions performed during all major temple ceremonies and festivals (Pereira 1981; Rubinoff 1988; Thomaz 1981/82; Henn 2014).

Anchored thus in pre-colonial village traditions, which linked social, economic, and ritual privileges and hierarchies, one or sometimes more temples enjoy the highest status today in every village or town by a) being the primary abode of the grāmadevi or grāmadeva, that is village goddess or village god, b) being patronized and administered by the ganvkar/ mahäjan and c) being located on and sustained by a central and fertile plot of the village land. This social status of the village temples was formally codified when, in 1881, the Portuguese colonial administration instituted the Regulamento dos Mazanias or Rules of the Mahajjan, ordering the compromisso or legal registration of all Hindu temples and the documentation of their main deity or deities, mahäjan trustees, properties, incomes, expenses, and major festivals (Gomes Pereira 1978:26).

The best known grāmadevatās in Goa today are Shantadurgā, Mahālakshmī, Kamakshī, and Saterī, among the female deities, and Mangesh, Nagesh, Ravaḷnāth, and Vețāl, among the male deities. In the majority of villages and towns the various social and ritual hierarchies cohere. That means the ranking of ganvkar and vangod combines high status in the village economy and society with the high standing of mahäjan and privileged mān in the principle temples. Also, all involved groups typically belong to the higher ranks in the caste system. It is therefore safe to say that most principle temples in Goa today are run by local elites.

This social status of the principle village temples implicates a number of normative practices and stipulated representations. First and most conspicuous are the norms and practices stipulating that the mūrti, the image or icon, of the grāmadevī or grāmadeva of a village temple is to be made by a śilpī, a specialist who follows the śilpaśästras, ancient directions for image-making. Moreover, the image is to be formally installed in the temple in a ritual ceremony, pratisțha, that establishes prāna, the breath of life, into it, thereby ideally initiating its continuous handling and service by Brahman priests (Preston 1985; Eck 1981). Pratisțhā ceremonies are performed in Goa when a new temple is inaugurated and consecrated, or when icons in existing temples are moved or replaced due to major construction works. When one asks people, in particular Brahmans, what distinguishes a temple from a devuli or gumptī, they most commonly refer to this formal making and installing of the icon or icons.

11 The normative practices and representations that constitute a formalized shrine usually further imply that grāmadevatās, in one way or another, are related to deities mentioned in one of the famous Hindu scriptures. In Goa, this is most commonly the Sahyādrikhanḍa of the Skanda Purāna, commonly circumscribed as the "Book of the Western Mountains" (Axelroth and Fuerch 1998:451). Therein can be found and are referenced-although 
rather disparately and unsystematically, as scholars point out (Levitt 1977)-not only the names and some characteristics of most Goan village gods, but also mythological stories about the main Brahman castes and clans of Goa. Iconographic details and local mythology characterize grāmadevatās most commonly as queens or kings who, equipped with royal paraphernalia and commanding over the group of lower deities and tutelary beings, rule over the village realm and protect its people and resources.

The ceremonies, festivals, and rituals performed in and around village temples can be said to represent and enact the social hierarchies prevalent in the villages and towns. Ganvkar and mahäjan are clearly distinguished from common villagers and visitors. They may sit on separate or elevated platforms and usually stand out by wearing particular ceremonial items of clothing such as turbans or pachodī, colored shawls, or just by having a flower petal stuck behind their ears. Such a petal signals that they have received the prasāda or sacred "food" that has been exchanged with the goddess or god. In fact, the exact order in which the ceremonies and rituals are organized and performed also reflects and represents the hierarchy prevailing among the people participating in them. That is, ganvkar and mahäjan of the first vangod usually receive the first prasāda, walk in the first row during the village processions, and carry the icon of the village god. Representatives of the second, third and subsequent vangods follow in order, take locations more and more distanced from the icon, and carry other or no paraphernalia at all during the processions. Common villagers usually follow the dignitaries and partake in the ceremonies only at an appropriate distance; those who belong to tribal or Dalit communities watch from outside the temple and from afar.

Besides the village temples, there are many devuli and gumptī in villages and towns. These religious structures may have images of the local ganvdevi or ganvdeva or of other Hindu deities or tutelary beings. They often display collections of various types of deities and tutelary beings. The subordinate status of these structures is based on the fact that their deities are not associated with the village at large, but only with certain village quarters, bairros or vāde, or with particular locations, jāge. The deities and tutelary beings of devuli and gumptī are taken to protect the areas and locations they are associated with. Some of them are therefore known under generic names such as rakhno, kșetrapāl "guardian," or devuncār, "wandering god" (indicating that he continuously walks the territories he protects). Indicative of their protective function, devuli and gumptī are most commonly found at liminal or dangerous locations such as the boundaries between settlements, fields, and forests; they are also located at bridges and crossroads, on the banks of rivers, and at the seashore. Devuli and gumpti are also widespread in cities and urban areas and can be seen most commonly at intense and critical traffic spots and at locations associated with risk of bodily injury or danger to life, such as train, bus, and taxi stations, traffic lights, hospitals, industrial plants, factories, workshops, electrical poles, river sluices, elevators, etc. As an extension of these public shrines, many private shrines can be seen in and outside of people's homes and shops, and images, names, and tokens of deities and tutelary beings mark many cars, two-wheelers, boats, and buses.

In the pre-colonial and colonial past, the typical patrons of devuli and gumptī were people who came from outside the villages to perform services for the village communities. These services included the priestly and scribal activities of certain Brahmanical jātis or occupational castes (Chitpavan, Shenvi), the administrative and trading occupations of Kshatriya (Maratha) and Vaishya (Vani) castes, specialized agricultural and artisanal castes (Bhandari, Mithgaude, Shet), and manual labor of Sudra, tribal, and Dalit 
populations. Each one of these occupational groups ideally settled in a separate quarter of the village or town, where they had their places of worship. While this pattern is active to this day in the sense that most, if not all, devuli and gumpti are patronized by groups other than the traditional ganvkar, the sociological composition of the patrons of public shrines, above all in the cities, is of course much more diversified and fluctuating. Besides the people living and settling in the vicinity of devuli and gumptī, patrons of the shrines often come from modern occupational groups such as shopkeepers, taxi drivers, office workers, and business employees who work nearby.

\section{Emergent Shrines}

15 A second look reveals that underneath the surface of the social forces and practices that produce and sustain the formalization of the shrines lies another, subordinate yet resilient and influential set of social attributions and iconographic distinctions having to do with the origination or emergence of the shrines. To begin with the village goddess most widely worshipped in Goa today, Śāntādurgā, it is important to note that her iconography as a royal woman armed with sword and shield quite literally hides the fact that most, if not all, ancient village goddesses were not represented by any icon or image at all. Instead, they were embodied and represented by natural objects, termite mounds, trees, and unworked stones or their icons often showed only a minimum of man-made artisanal impact. This holds true for the entire group of ancient Konkan village goddesses Saterī, Morjaī Maulī, Kelbaī, Reṇukā, and Bhūmikā, for all of whom old temples, archaeological findings, archival sources, and local folklore reveal what scholars call aniconic representations. This implies in particular the manifestation of the most widespread and best documented old Konkan gramādevi Saterī in the form of termite mounds or roen. Still existing actively worshipped roen can be found in the districts of the New Conquests of Goa and the adjacent Konkan regions of Maharashtra. They show often impressively large termite mounds with more or less rich devotional decor in the midst of temples that have obviously been carefully erected around them. Many smaller shrines and locations revealing signs of the worship of termite mounds are scattered all over the Konkan region, including the Goan districts of the old Conquest. Indological studies evidence that the worship and ritual service of termite mounds (Sanskrit: valmika or valmikāvapa ), reach back to Vedic times. They associate the literal meaning of valmika and valmikāvapa, among other things, with "soil" and "earth" and etymological connotations including "to beget, procreate" and "to strew, scatter," in particular in reference to "seed" (Smith and Carri 1994:202). Local mythology and folklore in Goa and the Konkan highlights, above all, that roen evidence the emergence of the goddess out of the earth, underscoring thereby the self-agentive nature of her manifestation.

Similar connotations resonate in the manifestations of Morjaī, Maulī, Kelbaī, Renukā, and Bhūmikā, all of whose divine bodies are associated with the Konkani and Sanskrit notion of bhū or bhūmi, "soil" and "earth" (Monier-Williams [1899] 2006:763). This renders Bhūmikā into a generic category of earth goddesses comprising all of these old Konkan female gramādevatās. A most indicative iconic manifestation of this category is found in old temples where grāmadevis are represented by rudimentary stone icons of body parts such as a head or hand that is placed directly on the ground. Again, it is local mythology and folklore that associates these icons with the understanding that the goddess's body is, 
rather than represents, the soil and the ground that most existentially constitutes the village, its settlements, and its fields.

Ravaḷnāth and Vetāl are the oldest and most widely disseminated male village gods in Goa today. Anthropomorphic iconography shows Ravalnāth as a standing male figure with four arms, holding a sword, a trident, a bowl of ambrosia, and a kettle drum (Mitragotri 1999:164). Vetāl is portrayed as a standing, fully naked male figure (ibid. 169). A closer look reveals here as well deeper layers of rudimentary iconic and aniconic representations. Archaeological and folkloric evidence showing Ravalnāth or Vetāl as consorts of Saterī can be "found in practically every Goan village," writes P. P. Shirodkar (1988:17), the former director of Goan Archives, Archaeology, and Museums. The worship of Ravalnāth is in particular fused with Saterīs roen, or termite mounds, which in local mythology and folklore are praised as the preferred "homes of snakes," thereby reiterating the termite mounds" classic association with "sites of begetting." Accordingly, Ravalnāth is also often seen as a nāga or snake deity, whose veneration is well documented in the Konkan region (Shirodkar 1993). Nāga stones representing snake deities in sculptured icons or unworked rocks can be found, as Shirodkar (1993:6) puts it, above all, "[in] shrines holding subordinate positions." Vetāl is often seen as Bhairav, the frightful, terrible, and destructive manifestation of Śiva. In this rūpa or form, his theistic nature and iconographic representation seamlessly mix with those of the large category of tutelary beings called rakhne, deunchār, and kșetrapāl. Ravalnāth and Vetāl are represented in myriads of devuli and gumptī at trees and unmarked locations, with little to no man-made iconography. Often, they are simply marked by "a stone smeared with saffron" (Shirodkar 1988:16). Like all the ancient goddesses, they are most popular among the subaltern and marginalized sections and castes of Goa's society, Sudras, Dalits, and the tribal population. Their places of worship can often be found outside of temples where they are served by guranvs or ghaddis, that is, non-Brahmanical priests.

There are indications that many of the ancient village goddesses and gods have been historically transformed and superimposed upon by deities represented in formalized shrines. For example, Saterī, Morjaī, Maulī, Kelbaī, Renukā, and Bhūmikā are in many temples addressed and worshipped under the name of śāntādurgā today. In a number of old temples, roen can be seen covered by silver masks or anthropomorphic icons showing Śāntādurgā. Signs of Sanskritization-that is, ennoblement through Brahmanical names or iconography-can also be found for Vetāl and Ravaḷnāth. Vetāl's unusual iconographic representation as a nude male can be seen clad in a dhoti, a loincloth, in temples in which he is served by Brahmans. Ravalnāth's iconic appearance is often embellished with royal paraphernalia such as umbrellas, palanquins, and tarang (ceremonial poles).

Notably, though, the old names and representations of the ancient village gods are not only resilient and, as a rule, survive under their Brahmanical formalization. Quite obviously, their emergent character and diverse iconography also have a wide and popular appeal and have become a model for myriads of newly arising shrines throughout Goa. In fact, as I have elaborated in more detail elsewhere (Henn 2008), it is precisely the emergent character, local dispersion, and variable iconography of these shrines that makes them flourish in number and variety in the cities today, where they serve a changing, sociologically diversified, and fluctuating population. They not only prove able to adapt the old traditions of the wayside rakhne and devuncār to the hazards and concerns associated with modern traffic, industrial workplaces, and urban life, but also 
readily accommodate emerging trends of the worship of holy men and charismatic figures such as Shirdi Sai Baba and Satya Sai Baba.

Some of these emergent urban shrines grow enormously in size and popularity until they surpass the architecture and challenge the prestige of established temples. A case in point is the shrine or temple of Bodgeśvar in the town of Mapusa, Bardez. Its origins can be traced back to an aniconic shrine near a bongi-tree (Pandanus Tectorious Soland) dedicated in the mid-1930s to a tutelary being, appropriately named Bodgi, who combined the characteristics of a border-guarding rakhno and a sadhu or Hindu ascetic. In the 1960's, the shrine evolved into a small, concrete devuli displaying a small icon of a devuncār or wandering guardian. Gradually attracting the worship and patronage of a group of successful business castes of Mapusa, Boḍgi was eventually ennobled to Śrī Dev Bodgeśvar and is represented today by a larger-than-life anthropomorphic icon in a large, officially registered temple hall drawing, on his annual feast day in December/ January, the largest crowd of worshippers and visitors of all the temples in Mapusa (Henn 2006).

\section{Catholic Shrines}

\section{Formalizations}

21 A first and striking impression one gets when looking at Goa's churches is how much their exterior appearances, their locations, and even their social organization resemble those of Hindu temples. There is a background to this resemblance. In the early period of the Portuguese-Catholic conquest and colonization of Goa in the sixteenth and seventeenth centuries, the incoming rulers intended the churches they erected not simply to provide new places of worship for the gentiles of the territories of the Island of Goa, Bardez, and Salcette who could be persuaded to convert to the "Holy Faith." The newly established Catholic churches were also meant to replace the Hindu temples in all possible respects: physically, economically, socially, and, to some extent, even liturgically.

What resulted (and prevails to this day) from this radical replacement strategy is that Goan churches, on the one hand, operate very much like Hindu temples in a historically grounded Indian village organization and, on the other hand, represent a distinct Catholic culture that reflects Portuguese social traditions. Many, if not all, old Catholic churches in the districts of the old Conquest have been built in places where Hindu temples were formerly located. The emerging local Catholic communities largely emulated the social organization of the existing Hindu communities. They likewise distinguished ganvkar clans from common villagers and replicated, with few modifications, the Hindu caste ranks. Catholic Bahmon and Chaddi (Chardo) castes substituted the three highest Hindu castes (merging Hindu Kshatriya and Vaishya groups in the Catholic Chaddi). Catholic Sudir preplaced Hindu Sudra and the tribal and Dalit communities Gaudha, Velip, Mahar and Chamar spilt up into Hindu and Catholic sections (D'Costa 1977). One additional elite class or caste, the Castiços or Descendentes (Dalgado 1988 I:229, 355), who claimed mixed Goan and Portuguese descent, was added at the top of the Catholic hierarchy.

The local Hindu institutions of the mahājan found its equivalent in the Catholic confrarias or brotherhoods. Besides the religious orders of the Franciscans, Jesuits, and Dominicans, 
the various ecclesiastic officials of the Goan archdiocese (instituted in 1533), and the local churches, the confrarias had the strongest social impact and political power in the villages and towns of Goa. They were recruited from the local ganvkar clans and combined in themselves characteristics of the militant religious orders in Goa and religious privileges of feudal classes and artisanal guilds in Portugal. Their formal institution in Goa goes back to the year 1541, when the first confraria on the Island of Goa was established under the name Confraria da Conversão à Fé (Rocha 1973:6). Codified in written statutes, the formalization of the local confraternities laid the groundwork for the legal registration, or compromissos, first of the Catholic churches and later of the Hindu temples in Goa.

Like the Hindu mahäjan, the Catholic confrarias were, and are to this day, themselves stratified in vangods, which reflect a gradation of ritual privileges and honors in church ceremonies and festivals. Hence, in every village that has a considerable Catholic population, there exists a Confraria Maior that is constituted by clans holding high casteand vangod-status. In the colonial period, there existed high-ranking confraternities that were exclusively constituted by clans of descendentes. Members of the high-ranking confraternities hold special privileges in religious ceremonies. They sit in the first row of the pews during the festive Mass held at the annual holy days. During religious processions on Corpus Christi, Easter, sorod (first crop), and the patron-saint's feast, they stand out in special colored festive capes and carry the images and paraphernalia of the saint or saints. Members of lower-ranking castes or vangods constitute one or more Confraria Menor. They are marked by differently colored capes in the processions, sit and walk at second or third-ranked positions in the ceremonies and processions, and hold subordinate ritual privileges. In some villages, the hierarchy between confraternities is marked by a distinction and gradation of the saints themselves that are venerated in the village. Hence, Santos Titulares, saints recognized as the formal patron saints of the village, are patronized by the members of the Confraria Maior, and Santos Menores, saints that are associated with the chapels scattered in the village, are patronized by the members of the Confraria Menor.

Following ecclesiastic laws that were codified inter alia at the Council of Trent (1545-1563; Session XXII), all Catholic churches in Goa are formally consecrated through rites performed by a bishop. These rites include, as mentioned before, the placement of a relic of Christ or a Catholic martyr in a casket or shrine in the church altar (Catholic Encyclopedia: consecration). More importantly, the formal status of the churches is based on their association with one or several patron saints from the corpus of the officially canonized Catholic saints. Reflecting historical trends from the times when the churches were built or, in separate, likewise ritually formalized acts, dedicated to their patrons, many Goan Catholic patron saints belong to the circles of canonized persons that were favored by the leading religious orders of Franciscans, Jesuits, Dominicans and Augustinians. Historically continuous but shifting forms of Marian worship in Goa mark the source of numerous Goan church dedications to Mary. Churches are also dedicated to various generic or material aspects of Catholic divinity such as Jesus Christ, the Holy Trinity, or the Holy Cross.

Many icons and images representing patron saints are said to have been imported from Europe. Some claim origins from the time of the first arrivals of missionaries, others refer to "holy places" such as Rome, Fatima, or Lourdes. A number of Catholic icons and images have gained particular local significance by becoming part of a local mythology telling about their arrival, placement, migration and, above all, miraculous powers. 
27 Next to its churches, Goa is marked by countless kopel and khuris, chapels and crosses. Some of the kopel are formally related to the village churches. They usually have the shape of small churches, are similarly dedicated to distinct saints, and are occasionally or permanently served by ordained vicars or priests. Their patrons are, as mentioned, the members of subordinate confraternities and people living in their vicinity. Smaller kopel, as well as khuris (white-washed stone crosses) and grotto-shaped structures scattered in the hundreds and thousands in Goa's villages, towns, and countryside, have a much more informal status. Like the Hindu devuli and gumptī, and often in their immediate vicinity, they are most commonly located at places considered liminal or dangerous, such as the boundaries between settlements, fields, and forests; bridges; crossroads; the banks of rivers; and the seashore. They may or may not be associated with specific saints, may or may not display icons or images, and may or may not have stone altars, gated structures, and roofs added to them. Similar, again, to the Hindu devuli and gumptī, the sociological composition of the patrons of these smaller Catholic kopel and khuris is diverse and fluctuating. In particular in cities, patrons may be people living in the vicinity of the shrines, or people who work nearby or just regularly pass by.

\section{Iconic Shrines}

The formalized shrines in the Catholic domain are also challenged by certain formally refuted yet practically tolerated social attributions that have to do, in their case, with their icons and iconicity. In order to understand the peculiarity of the icons here and to see how it contrasts with the formalized shrines, it is necessary to take a brief look at the historically deep debate in the Christian world over the theological validity and practical use of religious images. In Europe, this issue goes back to a controversy over the foundational ban of the worship of images in the Old Testamentary Decalogue that has erupted at various times in the history of the Church. The controversy triggered major iconoclastic violence in the medieval period against the use of icons in the Byzantine Church and, at the time of the Protestant Reformation, against the use of images in the Catholic Church. Counter-currents to the rejection and suppression of religious images through the centuries were the often elaborate religious iconography in religious and aristocratic buildings and even many common people's houses, and the popular and widespread veneration of relics and images throughout Christian Europe (Brown 1981, Freedberg 1989, Christian $1981 \mathrm{a}$ and b). It is of particular relevance for a discussion of the circumstances in Goa that the theological renewal of the Catholic Church in response to the Protestant Reformation that took place inter alia at the Council of Trent (1545-1553) propagated the radical suppression of so-called idolatry in the emerging colonial world and issued particular restrictions on the use of images in Catholic churches and practice (Jedin 1935, Belting 2000). One direct result of this renewal was the violent campaign, executed by the forces of the Portuguese crown and the Catholic orders, that led between 1540 and 1580 to the destruction of most temples, mosques, and religious iconography of the native population in the districts of the Island of Goa, Bardez, and Salcette (Henn 2014).

29 It is against this background that a number of Catholic shrines - both shrines which belong to churches and independent shrines - deserve attention. These are shrines that are celebrated in local mythology and folklore, as well as in the media today, for performing miracles. This means that practices performed at these shrines, prayers or 
rituals, are not just seen as symbolic acts of worship or enactments of a symbolic communication with the saints or the divinity represented in the shrines, but are taken to yield physical effects. Most commonly in Goa, these physical effects or miracles are thought to be bodily transformations, such as cures of illnesses, the conception of a child, or other mostly beneficial effects for the person who interacts with the shrine.

Most outstanding in this regard is the shrine and icon of St. Francis Xavier (1506-1552), the Jesuit who lived and worked in Goa and South India from 1541 to 1546, before he journeyed on, via Portuguese Mallacca, to China, where he died in 1552. Buried and exhumed twice, in China and Mallacca, the mummified body of Francis Xavier was brought back to Goa in 1553, where it is laid out today in a glass sarcophagus in the Basilica of Bom Jesus in Old Goa (Pinch 2011). Canonized in 1619 and attributed with countless miracles, St. Francis Xavier is today by far the most popular saint among Catholics in Goa. He is the patron saint of many Goan villages, and his image is displayed in the hundreds in chapels and at crosses. He attracts thousands of worshippers during his annual feast day in December, many of whom come to pray and make vows at his shrine in the hope of being blessed by a miracle.

famous example is Our Lady of the Miracles, popularly known as Milagres since Portuguese times, who is associated with the biggest church in the town of Mapusa. Nomen est Omen, Milagres also has a long saga of performing miracles and is, therefore, visited and celebrated by thousands of worshippers and solicitants every year. She is famous in particular for attracting both Catholics and Hindus, who can be seen lining up in the churchyard before her images on her feast day in May.

A third noteworthy example is Fulanco Khuris, the Flower Cross, a small white-washed wayside cross at the boundary of Goa's capitol Panjim, right next to Highway 17. It is named after the fact that worshippers and, above all, by-passing drivers of motorcycles, rikshaws, cars, taxis, trucks, and busses, constantly shower the cross with so many flower garlands that, most of the time, its structure is hardly to be seen. Again, the reason for the exuberant appreciation of Fulanco Khuris is that it is locally known for its miraculous powers, which reportedly have healed many people. Visible on old photographs, the cross's growth in popularity can be reenacted from its beginnings in the 1940s, when it was just a simple whitewashed stone cross, like hundreds of others scattered in the landscape of Goa. In the mid-1960s, it then got a small sheet-iron roof and a gate. In the 1990s these were replaced by a large, futuristic-looking cement structure, with a high belfry next to it, capable of sheltering perhaps 300 people.

All these shrines are entwined in the local mythology and folklore by numerous stories about the miracles they are said to have performed, stories that are regularly revitalized at their annual feast days in the local print media and, of late, also on the local TV channels and the internet. St. Francis Xavier's miracles, for instance, are most effectively condensed in the arguably inexplicable resistance to decay of his "incorruptible body"; Milagres' astonishing attraction to Catholics and Hindus is grounded in a legend that makes her the converted sister of seven local Hindu ganvdevi; and Fulanco Khuris' story usually includes the long list of miraculous cures that it is said to have performed for people visiting, especially from the nearby hospital of Goa Medical College.

Ironically, although consistent with the centuries-long Christian concern about so-called idolatry, in all the miracles these shrines are celebrated for, the images or icons displayed at the shrines, or the shrines themselves play an extraordinary role. That is, it is the material objects that, so-to-speak, enact the miracles. In other words, the shrines, icons 
and images are not just incidentally or by the symbolic representation of the sacred agents they stand for involved in the attributed occurrence of the miracles, but play a substantial and active role in the happenings. ${ }^{7}$ Fulanco Khuris, for instance, like many other khuris, is not dedicated to any particular saint and its association with Christ, although theologically established, is so abstract in local perception that the little cross itself is basically seen as the agent of the miracles.

In the case of St. Francis Xavier, it is the relic of his body that takes the core position in the miracles attributed to him. ${ }^{8}$ Many Goans not only feel especially protected by the fact that his body is, so-to-speak, amidst them; they even reduce the saint to his body by addressing him in their devotional evocations simply as the kudh, body. In the past it was the relic itself, today the shrine containing the relic, that is the object of vibrant ritual practices. These practices are in particular the pilgrimages that people from near and far undertake throughout the year, and especially on the saint's feast day in December, in order to pray and make vows at the shrine of the saint. Especially highly celebrated are the "Expositions of St. Francis Xavier" that are held every ten years, during which the sarcophagus is lowered from its normally high location in the Basilica of Bom Jesus and carried over in a solemn procession to the Se Cathedral in Old Goa, where it is made accessible. People line up in the thousands to take a close look at the relic, touch the shrine, kiss it, and circumambulate it, if possible, a couple of times. In all these practices, it is obviously the physical presence, bodily proximity, corporeal contact, and sensual experience of the relic that are at the core of its attributed miraculous effects.

In the worship of Milagres of Mapusa, iconography also plays an important role. Every year, at her feast day in May, two images of the saint are placed outside the church in temporary shrines. One is the life-sized wooden sculpture of the saint that is normally located on one of the church's side altars; the other is a smaller, less intricately worked, more boldly colored wooden sculpture. Both these images are made accessible for people outside of the church only during the feast day, when the number of worshippers, as mentioned, swells to several hundred, including both Catholics and Hindus. Intriguingly, the stream of worshippers is divided then between the images. Catholics line up before the large image and present candles and flower garlands to it. Hindus line up before the smaller image and pour coconut oil over it, an offering commonly made to Hindu deities. That people of both groups are united in the expectation of particular miraculous effects becomes visible, among other things, in another ritual practice that many of them perform. This is the offering of miniature wax models, sold at the site, either of babies or of body parts, heads, legs, kidneys, or torsos, meant to invoke the saint's interference in conceiving a child or in healing an illness of a part of the body.

\section{Conclusion}

As this analysis of materials from Goa confirms, no definite and clear distinction can be drawn between shrines on the one hand and temples and churches on the other. Variations and distinctions are evident only with regard to the effects of the social stratifications and political power relations that determine the formalization and patronage of the shrines. This formalization and patronage is effectively carried out by the local elites and reflect more than local structures that link social, economic, and ritual privileges and hierarchies. Far-reaching social, legal, and administrative power formations are also operative, such as the Indian caste system and the hierarchy of the 
Catholic Church. Moreover, the shrines are still noticeably impacted by administrative regulations that reach back to the period of Portuguese colonialism and Catholic hegemony in Goa, from 1510 to 1961.

Intriguingly, the established hierarchies and power relations can, however, also be seen to be challenged by counter-currents that themselves reflect old and profound premises and practices related to shrines. In the Hindu domain, these premises and practices reach back to the formation of ancient temples and reveal, above all, the emergent manifestation of village goddesses, gods, and tutelary beings. In the Catholic domain, assumptions and practices associated with shrines have been historically influenced by long-lasting Judeo-Christian controversies over so-called idolatry; they demonstrate, above all, the popular appeal of shrines attributed with miraculous power. Shrines in Goa today keep these traditions and controversies alive. Emergent Hindu shrines have not only survived beneath the surface of their historical subordination by formalized shrines. They also continue to materialize in large numbers today as deuvli and gumptī, some of which surpass the established temples in size and popularity. Similarly, Catholic icons, images and shrines celebrated for peculiar miraculous powers have not only held their ground inside and outside of churches against the historical accusations of so-called idolatry. Today many of them have pushed themselves into the forefront of public attention and outshine the established churches, despite lacking official theological endorsement. In general, both the emergent Hindu and the miraculous Catholic shrines bring to bear premises and practices that highlight processes of embodiment, the appreciation of materiality, and sensual experience, in stark contrast to the emphasis on representation, symbolism, and social prestige that is prominent in the more formalized shrines.

The use of the term "shrine" does not usually reflect the multiple conditionalities and contexts at stake in the constitution, endurance, and contestation of its referent: elite formalization, political subordination, demotic resilience, cultural variation, semiotic shifts and, at times, iconoclastic destruction. It goes beyond the scope of this article but deserves mentioning that the currently evolving criticism of a universalist concept of religion highlights precisely the shortcoming of approaches that define religion primarily as a system of symbols and representations. It is argued that these approaches neglect to reflect historical contexts and political power relations operative in the emergence of the concept of religion and overlook, in particular, the critical significance of semiotic ideologies, forms of embodiment, materiality, and practice at large (Asad 1993; Keane 2004; Bell 1992, 2006; Bourdieu 1989). In the end, therefore, "shrine"-as Catherine Bell (2002:104) said about "religion"-may just be an "over-reaching folk category" that obscures and hides more than it brings to light.

\section{BIBLIOGRAPHY}

Asad, Talal. 1993. Genealogies of Religion: Discipline and Reasons of Power in Christianity and Islam. Baltimore: John Hopkins University Press. 
Axelrod, Paul and Michelle Fuerch. 1996. "The Flight of the Deities: Hindu Resistance in Portuguese Goa." Modern Asian Studies 30(2):387-421.

Bayly, Susan. 1989. Saints, Goddesses and Kings: Muslims and Christians in South Indian Society 17001900. New York: Cambridge University Press.

Bell, Catherine. 1992. Ritual Theory, Ritual Practice. Oxford: Oxford University Press.

Bell, Catherine. 2002. "The Chinese Believe in Spirits: Belief and Believing in the Study of Religion." Pp. 100-17 in Radical Interpretation in Religion, edited by N. Frankenberry. New York: Cambridge University Press.

Bell, Catherine. 2006. "Paradigms Behind (and Before) the Modern Concept of Religion." History and Theory 45:27-46.

Belting, Hans. 2000. Bild und Kult: Eine Geschichte des Bildes vor dem Zeitalter der Kunst. München: Beck.

Bourdieu, Pierre. 1989. The Logic of Practice. Translated by R. Nice. Cambridge: Polity. Brown, Peter. 1981. The Cult of Saints: Its Rise and Function in Latin Christianity. London: SCM.

Catholic Encyclopedia. “Consecration.” Retrieved February 1, 2018 (http://www.newadvent.org/ cathen/04276a.htm).

Catholic Encyclopedia. “Chapel.” Retrieved February 1, 2018 (http://www.newadvent.org/ cathen/03574b.htm).

Christian, W. A. Jr. 1981a. Apparitions in Late Medieval and Renaissance Spain. Princeton: Princeton University Press.

Christian, W. A. Jr. 1981b. Local Religion in Sixteenth-Century Spain. Princeton: Princeton University Press.

Dalgado, Sebastião Rudolpho. [1918] 1988. Glossário Luso-Asiatico. 2 vols. New Delhi: Asian Educational Services.

Diehl, C. G. 1965. Church and Shrine: Intermingling Patterns of Culture in the Lives of Some Christian Groups in South India. Uppsala: Almqvist \& Wiksell.

Eck, Diana. 1981. Darsán: Seeing the Divine Image in India. Chambersburg, PA: Anima Books.

Freedberg, David. 1989. The Power of Images: Studies in the History and Theory of Response. Chicago/ London: University of Chicago Press.

Gune, Vithial Trimbak. 1965. Ancient Shrines in Goa. Panjim: unknown publisher.

Gupta, Pamila. 2004. "The Relic State: St. Francis Xavier and the Politics of Ritual in Portuguese India." PhD dissertation, Columbia University, New York.

Henn, Alexander. 2006. "The Lord of Mapusa: Genesis of an Urban God in Goa." Purushartha 25:3147.

Henn, Alexander. 2008. "Crossroads of Religions: Shrines, Mobility and Urban Space in Goa." International Journal of Urban and Regional Research 32(3):658-70.

Henn, Alexander. 2014. Hindu-Catholic Encounters in Goa: Religion, Colonialism, and Modernity, Bloomington: University of Indiana Press.

Jedin, H. 1935. "Entstehung und Tragweite des Trienter Dekrets über die Bilderverehrung." Theologische Quartalsschrift CXVI:143-88, 404-29. 
Keane, Webb. 2004. "Language and Religion." Pp. 431-48 in A Companion to Linguistic Anthropology, edited by A. Duranti. Malden: Blackwell.

Kothari, Komal. 1982. “The Shrine: An Expression of Social Needs.” Pp. 3-51 in Gods of the Byways: Wayside Shrines of Rajasthan and Gujarat, edited by J. and D. Elliott. Oxford: Museum of Modern Art.

Kowal, David. 2001. "The Hindu Temples of Seventeenth- and Eighteenth-Century Goa: The Maintenance of a Sacred Integrity and the Process of East-West Cross Fertility." Portuguese Studies Review 9(1-2):398-434

Kramrisch, Stella. 1983. “Unknown India: Ritual Art in Tribe and Village.” Pp. 87-120 in Exploring India's Sacred Art: Selected Writings of Stella Kramrisch, edited by B. Stoler Miller. Philadelphia: University of Pennsylvania Press.

Levitt, H. 1977. "The Sahyādrikhanda: Some problems Concerning a Text-Critical Edition of a Puranic Text." Purana 19(1):1-40.

Mitragotri, V. R. 1999. Sociocultural History of Goa: From Bhojas to Vijayanagara. Panaji: Institute Menezes Braganza.

Mitterwallner, Gritli von. 1982. “The Rock-Cut Cave Temples of Arvalem Goa." Pp. 165-74 in Madhu: Recent Researches in Indian Archaeology and Art History, Shri M.N. Despande Festschrift, edited by M. S. Nagaraja Rao. Atlantic Highlands, NJ: Humanities Press.

Mitterwallner, Gritli von. 1983a. "Testimonials of Heroism: Memorial Stones and Structures." Pp. 41-49 in Goa: Cultural Patterns, edited by S. Doshi. Bombay: Marg Publications.

Mitterwallner, Gritli von. 1983b. “The Hindu Past: Sculpture and Architecture.” Pp. 21-40 in Goa: Cultural Patterns, edited by S. Doshi. Bombay: Marg Publications.

Monier-Williams. [1899] 2006. English Sanskrit Dictionary. Springfield, VA: Nataraj Books.

Mosse, David. 1994. “Catholic Saints and the Hindu Village Pantheon.” Man 29(2):301-32. Pereira, Rui Gomes de. 1978. Goa: Hindu Temples and Deities. Panaji Goa: Printwell Press Goa. Pereira, Rui Gomes. 1981. Goa: Gaunkari, the Old Village Associations. Panji: Privately Published. Pinch, William R. 2011. “The Corps and Cult of St. Francis Xavier.” Pp. 113-32 in Engaging South Asian Religions: Boundaries, Appropriation, and Resistances, edited by M. N. Schmalz and P. Gottschalk. Albany: State University of New York Press.

Preston, James. 1985. "Creation of the Sacred Image: Apotheosis and Destruction in Hinduism." Pp. 9-30 in Gods of Flesh, Gods of Stone: The Embodiment of the Divine in India, edited by J. Waghorne and N. Cutler. Chambersberg, PA: Anima.

Raj, Selva J. 2002. "Transgressing Boundaries, Transgressing Turner: The Pilgrimage Tradition at the Shrine of St. John de Britto." Ritual Studies 16(1):4-18.

Rayamma, P. 1982. St. Francis Xavier and his Shrine. Panjim: unknown publisher.

Rocha, Leopoldo da. 1973. As Confrarias de Goa (Seculos XVI-XX) Conspecto Histórico Jurídico. Lisbon: Centro de Estudos Históricos Ultramarinos.

Rubinoff, Janet Ahner. 1988. "Vangad: The Concept of Lineage in a Goan Corporate Village." Pp. 191-207 in City, Countryside and Society in Maharashtra, edited by D. W. Atwot, M. Israel and N. K. Wagle. Toronto: University of Toronto.

Shirodkar, P. P. 1988. "Influence of Nāth in Goa." Pp. 8-21 in Goa: Cultural Trends, edited by P. P. Shirodkar. Panjim: Directorate of Archives, Archaeology and Museum. 
Shirodkar, P. P. 1993. "Nāga Worship in Goa." Presented at the ICSS Workshop on Goan Folklore: Theories, Perspectives, and Methodologies, April 16, Goa University, Department of History.

Smith, Frederick and S. J. Carri. 1994. "The Identity and Significance of the valmïkavapa $\bar{a}$ [anthill] in the Vedic Ritual." Indo-Iranian Journal 38(3):201-31.

Stein, Burton. 1973. "Devi Shrines and Folk Hinduism in Medieval Tamilnadu." Pp. 75-79 in Studies in the Language and Culture of South Asia, edited by E. Gerow and M. O. Lang. Seattle/ London: University of Washington Press.

Stirrat, R. L. 1982. "Shrines, Pilgrimage, and Miraculous Powers in Roman Catholic Sri Lanka." Pp. 385-413 in The Church and Healing: Studies in Church History, edited by W. Sheils. Oxford: Basil Blackwell.

The Oxford English Dictionary. 1989. $2^{\text {nd }}$ Edition. Oxford: Clarendon Press.

Thomaz, Luis Filipe. 1981/82. “Goa. Une Société Luso-Indienne.” Bulletin des Études Portugaises et Brésiliennes 42-43:15-44.

Ventura, Robert. 2014. “Tombos dos Pagodes: Mapping the Religious and Social Context of Rural Goa in the Early Modern Period.” Pp. 321-52 in Intercultural Encounter and the Jesuit Mission in South Asia (16th-18th Centuries), edited by Anand Amaladass and Inez Županov. Bangalore: Asian Trading Corporation.

Zedler, Johann Heinrich. 1731-54. "Schrein," Grosses vollständiges Universal-Lexicon aller Wissenschafften und Künste, Vol. 35:596. Retrieved February 7, 2018 (https:// www.zedler.lexikon.de/index.html? c=blaettern\&id=319761\&bandnummer=35\&seitenzahl=0596\&supplement=0\&dateiformat=1).

\section{NOTES}

1. I would like to thank the anonymous SAMAJ reviewers for their insightful comments on the first draft of this article. Anne Feldhaus generously copy-edited my English and helped with the diacritics. I thank Gabriele Henn and Gaspar D'Souza for the photographs.

2. Works dealing with Hindu shrines that are relevant for my analysis are Stein 1973, Eck 1981, Kothari 1982, Kramrish 1983 and Preston 1985. Important works dealing with Catholic shrines in historical Europe are Brown 1981 and Christian 1981a and b; Catholic shrines in India and South Asia are discussed in Bayly 1989, Mosse 1994; Raj 2002, and Stirrat 1982.

3. I use the term "icon" in general for all artifacts and material objects that stand for, represent or embody the divine or holy in or at shrines. Where distinguished from images, icons specify three-dimensional as opposed to two-dimensional forms of representation or embodiment.

4. Vithial Trimbak Gune's Ancient Shrines in Goa (1965) deals exclusively with Hindu temples and may also be suspected of making, at least implicitly, the assumption that shrines are distinctly Hindu structures.

5. In Goa, the arguably most outstanding Catholic shrine is the sarcophagus holding the mummified body of St. Francis Xavier in the cathedral of Bom Jesus in Old Goa (Rayamma 1982; Pinch 2011; Gupta 2004).

6. The territories of the Old Conquests came under Portuguese rule between 1510 and 1543 and included today's districts of Tiswadi (historically, Islands of Goa) Bardez and Salcete. Subdivided into two "mission fields" looked after by the Franciscans and the Jesuits, they experienced the full onslaught of early-modern enforced Catholic conversion and iconoclastic violence. The territories of the New Conquests came under Portuguese control only in 1763 and 1788 through political negotiations with the Adil Shah dynasty of Bijapur (Karnataka). They comprise today's 
districts of Ponda, Sanguem, Quepem, Canacona, Pernem, Bicholim, and Satari. Liberal tendencies in Portugal and strengthening Hindu polities in India prevented them from being exposed to the enforced conversion that had transformed the Old Conquests

7. For the large body of art-historical and anthropological studies that document the outstanding role that relics, icons, and images and the related materiality of bone, cloth, wood, earth, stone etc. of religious objects played-and, to this day, play-in the attribution of miracles, see Belting 2002 and Freedberg 1989.

8. For the complex role that St. Francis Xavier and his relic played in the politics of the Catholic Church, the Jesuits, and the Portuguese colonial empire in Asia, see Gupta 2004.

\section{ABSTRACTS}

Religious shrines in Goa (India), both Hindu and Catholic, are marked by notable differences. Shrines in temples and churches are distinguished from wayside shrines by their formalized iconography and elite patronization. Shrines are further differentiated by modalities of their representation and iconography. Formalized shrines fulfill particular representational (symbolic) functions that reflect local social hierarchies. Emergent Hindu and iconic Catholic shrines stand out through peculiar material and embodied characteristics of their iconography and enjoy wide demotic appeal. Although decisive for the role the shrines play in society, their inherent representational, semiotic, and practical distinctions and differentiations are usually not reflected in the concept of the "shrine." Eventually, the article, therefore, takes issue with this concept itself arguing that it is rather elusive and obscures more than it brings to light.

\section{INDEX}

Keywords: Hinduism, Catholicism, temples, churches, wayside shrines, icons, representation, embodiment, materiality, miracles

\section{AUTHOR}

\section{ALEXANDER HENN}

Arizona State University 